The Jocrnal of Vitaminolooy 5, $269-276$ (1959)

\title{
METABOLISM OF RIBOFLAVIN IN TUBERCULOUS PATIENTS
}

\author{
SHIN WATANABE \\ National Sanatorium, Toneyama Hospital, Toyonaka, Osaka
}

(Received June 23, 1959)

Previously, the author has measured the total amount of riboflavin in the urine and blood of tuberculous patients, and no significant difference was found among the patients having mild, intermediate and severe symptoms, and no riboflavin deficiency was detected. It was also reported that the metabolism differed in each individual, and the urinary riboflavin excretion was very different (1).

With regard to the human requirement of riboflavin as determined by load test, a lot of reports (2-9) are available: The requirement for Japanese is given to be $1.3 \mathrm{mg} /$ day for ordinary subjects and $2 \mathrm{mg} /$ day for hard laborers and lactating women (10). Generally, flavin mononucleotide (FMN) or flavinadenine dinucleotide (FAD) seems to be more effective than riboflavin. Especially, in case of administering antibiotics, FAD is reported to be preferable to riboflavin (11). As for the changes in blood riboflavin levels after loading with the vitamin in a variety of patients, it was found in tuberculous patients that the riboflavin level in blood corpuscles rose conspicuously from 30 minutes to one hour after the loading, and that in blood plasma elevated to a moderate degree (12).

The author has investigated the total amount of riboflavin and the amount of esterified riboflavin in the urine and blood of tuberculous patients, the effects of the amounts and types of riboflavin loaded and the formation of esterified riboflavin in the urine.

\section{EXPERIMENTAL}

Subjects - Subjects were chosen from the patients hospitalized in this hospital. The meals were restricted to those specified in this hospital, and no drug was given to them during the experiment. Tuberculous patients were classified just in the same way as introduced in the previous report.

Methods - Total urine for one day was collected, kept from exposure to light, and the blood was withdrawn before breakfast, taking care not to expose it to light.

Determination was made by lumiflavin method according to Fujita (13). Benzyl alcohol was utilized for separating esterified riboflavin from the free form. A fluorometer was used for the measurement. 


\section{RESULTS}

\section{Amount of Riboflavin in the Urine and Blood of Tuberculous Patients}

Five mild, 5 intermediate and 8 severe, tuberculous patients have been examined on their metabolism. Successively higher values were obtained from the severe to the mild in the amounts of total riboflavin and esterified form, in the percentage of ester to total riboflavin, and in the riboflavin discharged in the urine in one day; no significant difference was, however, found among the mild, moderately and severe patients (Table I). Moreover,

TABLE I

The Amounts of Total and Esterified Riboflavins in 24-Hour Urine of Tuberculous Patients

Figures are taken from each 5 patients with mild and moderately severe symptoms and from 8 patients of severe symptoms.

\begin{tabular}{|c|c|c|c|c|}
\hline & & Mild & Moderately severe & Severe \\
\hline $\begin{array}{l}\text { Total } \\
\text { riboflavin }(\mu g)\end{array}$ & $\begin{array}{l}\text { Average } \\
\text { Maximum } \\
\text { Minimum }\end{array}$ & $\begin{array}{c}102.2 \pm 45.9^{a} \\
169.1 \\
44.2\end{array}$ & $\begin{array}{c}87.8 \pm 35.1 \\
152.7 \\
47.2\end{array}$ & $\begin{array}{c}70.5 \pm 27.6 \\
118.8 \\
25.4\end{array}$ \\
\hline $\begin{array}{l}\text { Esterified } \\
\text { riboflavin }(\mu g)\end{array}$ & $\begin{array}{l}\text { Average } \\
\text { Maximum } \\
\text { Minimum }\end{array}$ & $\begin{array}{c}52.6 \pm 21.7 \\
71.3 \\
37.3\end{array}$ & $\begin{array}{c}35.4 \pm 14.4 \\
53.1 \\
20.4\end{array}$ & $\begin{array}{c}27.1 \pm 22.4 \\
69.6 \\
6.8\end{array}$ \\
\hline
\end{tabular}

${ }^{a}$ Standard deviation of the mean.

no influence of their age was apparent on the amount of esterified riboflavin discharged in the urine.

The level of riboflavin in blood also showed gradual higher values from the severe to the mild just as in the case of riboflavin in urine; this was, however, not a significant difference (Table II).

TABLE II

The Levels of Total and Esterified Riboflavins in the Blood of Tuberculous Patients

The number of cases of each severity were the same as Table I.

\begin{tabular}{llccc}
\hline & & Mild & Moderately severe & Severe \\
\hline \multirow{2}{*}{$\begin{array}{l}\text { Total riboflavin } \\
(\mu g / 10 O \mathrm{ml})\end{array}$} & Average & $6.3 \pm 1.8$ & $5.3 \pm 0.3$ & $5.8 \pm 0.7$ \\
& Maximum & 9.9 & 5.9 & 6.8 \\
& Minimum & 5.1 & 5.1 & 4.7 \\
\hline \multirow{2}{*}{$\begin{array}{l}\text { Esterified ribo- } \\
\text { flavin }(\mu \mathrm{g} / 100 \mathrm{ml})\end{array}$} & Average & $5.6 \pm 2.0$ & $4.5 \pm 1.2$ & $4.0 \pm 0.9$ \\
& Maximum & 9.4 & 5.9 & 5.1 \\
& Minimum & 3.1 & 3.1 & 2.1 \\
\hline
\end{tabular}

\section{Continuous Loading Experiment}

Each one of mild, moderate and severe tuberculous patients was given a 
hypodermic injection every other day of $1 \mathrm{mg}$ of riboflavin for 14 days, every day of $1 \mathrm{mg}$ of riboflavin for 5 days, and every day of $2 \mathrm{mg}$ of riboflavin for 5 days. After every loading, the urine was collected for 24 hours, and the average values for this period were sought. By this, significant difference was observed in the total amount of riboflavin in the urine as compared with the normal, when patients were loaded with $2 \mathrm{mg}$ of riboflavin every day for 5 days. The amount of esterified riboflavin was almost equal to the total amount of riboflavin of the normal (Table III). Further, the amount of riboflavin in the blood of the same patients was measured after withdrawing

TABLE III

Amounts of Riboflavin Excreted in the Urine after Continuous Loading

The figures are expressed in $\mu \mathrm{g}$.

\begin{tabular}{|c|c|c|c|c|}
\hline $\begin{array}{l}\text { Amount of riboflavin } \\
\text { administered }\end{array}$ & $\begin{array}{l}\text { Type of } \\
\text { riboflavin }\end{array}$ & $\operatorname{Mild}^{a}$ & Intermediate $^{b}$ & Severe ${ }^{c}$ \\
\hline Not loaded & $\begin{array}{l}\text { Total } \\
\text { Esterified }\end{array}$ & $\begin{array}{l}88.8 \pm 28.5 \\
25.0 \pm 6.6\end{array}$ & $\begin{array}{l}88.2 \pm 39.8 \\
23.9 \pm 6.5\end{array}$ & $\begin{array}{l}97.5 \pm 22.5 \\
38.5 \pm 12.0\end{array}$ \\
\hline $\begin{array}{l}1 \mathrm{mg} \text {, every other day, hypo- } \\
\text { dermic injection, for } 14 \text { days }\end{array}$ & $\begin{array}{l}\text { Total } \\
\text { Esterified }\end{array}$ & & & $\begin{array}{r}103.4 \pm 66.5 \\
40.8 \pm 13.1\end{array}$ \\
\hline $\begin{array}{l}1 \mathrm{mg} \text {, every day, hypodermic } \\
\text { injection for } 5 \text { days }\end{array}$ & $\begin{array}{l}\text { Total } \\
\text { Esterified }\end{array}$ & $\begin{array}{r}183.7 \pm 84.7 \\
65.8 \pm 15.8\end{array}$ & $\begin{array}{r}170.1 \pm 48.8 \\
73.8 \pm 24.3\end{array}$ & $\begin{array}{l}203.5 \pm 53.0 \\
100.7 \pm 28.0\end{array}$ \\
\hline $\begin{array}{l}2 \mathrm{mg} \text {, every day, hypodermic } \\
\text { injection for } 5 \text { days }\end{array}$ & $\begin{array}{l}\text { Total } \\
\text { Esterified }\end{array}$ & $\begin{array}{r}270.9 \pm 54.1 \\
80.5 \pm 36.1\end{array}$ & $\begin{array}{r}346.2 \pm 62.7 \\
52.6 \pm 12.3\end{array}$ & $\begin{array}{l}462.3 \pm 50.8 \\
120.0 \pm 23.0\end{array}$ \\
\hline
\end{tabular}

before breakfast on the following morning of the last day of loading and the total amount of riboflavin was fqund to be higher than the normal value,

TABLE IV

Amounts of Riboflavin in Blood after Continuous Loading

The figures are expressed as $\mu \mathrm{g}$ per $100 \mathrm{ml}$.

\begin{tabular}{|c|c|c|c|c|}
\hline $\begin{array}{l}\text { Amount of riboflavin } \\
\text { administered }\end{array}$ & $\begin{array}{l}\text { Type of } \\
\text { riboflavin }\end{array}$ & $\operatorname{Mild}^{a}$ & Intermediate $^{b}$ & Severe ${ }^{c}$ \\
\hline Not loaded & $\begin{array}{l}\text { Total } \\
\text { Esterified }\end{array}$ & $\begin{array}{l}6.4 \\
3.3\end{array}$ & $\begin{array}{l}5.9 \\
3.0\end{array}$ & $\begin{array}{l}6.0 \\
3.1\end{array}$ \\
\hline $\begin{array}{l}1 \mathrm{mg} \text {, every other day, hypo- } \\
\text { dermic injection for } 14 \text { days }\end{array}$ & $\begin{array}{l}\text { Total } \\
\text { Esterified }\end{array}$ & & & $\begin{array}{l}7.6 \\
4.1\end{array}$ \\
\hline $\begin{array}{l}1 \mathrm{mg} \text {, every day, hypodermic } \\
\text { injection for } 5 \text { days }\end{array}$ & $\begin{array}{l}\text { Total } \\
\text { Esterified }\end{array}$ & $\begin{array}{l}8.3 \\
6.1\end{array}$ & $\begin{array}{l}7.4 \\
5.6\end{array}$ & $\begin{array}{l}8.2 \\
5.0\end{array}$ \\
\hline $\begin{array}{l}2 \mathrm{mg} \text {, every day, hypodermic } \\
\text { injection for } 5 \text { days }\end{array}$ & $\begin{array}{l}\text { Total } \\
\text { Esterified }\end{array}$ & $\begin{array}{l}8.6 \\
6.2\end{array}$ & $\begin{array}{l}8.7 \\
5.2\end{array}$ & $\begin{array}{l}8.5 \\
5.8\end{array}$ \\
\hline
\end{tabular}


when $2 \mathrm{mg}$ of riboflavin had been loaded every day, and the amount of esterified riboflavin was on a par with the total amount of riboflavin of the normal (Table IV). From the above findings, it is known that for continuous loading with riboflavin, $2 \mathrm{mg}$ or more is required to make the experiment effective, i.e., to reach the esterified riboflavin levels as high as the total vitamin level of the unloaded. There was no significant difference among the mild, moderate and severe cases in the average values of riboflavin in this experiment.

\section{Loading Experiment}

Four tuberculous patients, both mild and severe, were loaded each with 2 or $5 \mathrm{mg}$ of riboflavin. After loading with $5 \mathrm{mg}$ of riboflavin, there was a significant difference in the amount of total and esterified riboflavin in comparison with the unloaded, but no significant difference was apparent between mild and severe patients (Table V). Five $\mathrm{mg}$ or more of riboflavin was

TABLE V

Amounts of Riboflavin Excreted in the Urine after Loading

The figures are the averages of 4 cases, expressed as $\mu \mathrm{g}$.

\begin{tabular}{llcc}
\hline $\begin{array}{c}\text { Amount of riboflavin } \\
\text { administered }\end{array}$ & $\begin{array}{l}\text { Type of } \\
\text { riboflavin }\end{array}$ & Mild & Severe \\
\hline \multirow{2}{*}{ Not loaded } & Total & $97.6 \pm 10.1$ & $71.6 \pm 9.6$ \\
& Esterified & $49.9 \pm 4.7$ & $28.4 \pm 9.2$ \\
\hline \multirow{2}{*}{ mg, hypodermic injection } & Total & $294.2 \pm 79.2$ & $232.4 \pm 56.8$ \\
& Esterified & $77.7 \pm 14.7$ & $41.1 \pm 9.3$ \\
\hline \multirow{2}{*}{ mg, hypodermic injection } & Total & $2394.0 \pm 420.0$ & $977.1 \pm 117.1$ \\
& Esterified & $124.2 \pm 31.8$ & $104.1 \pm 22.9$ \\
\hline
\end{tabular}

recognized to be required for the loading, when loaded once. There was no perceivable difference in the same patients between the normal values and the values measured on the following day before breakfast (Table VI). Thus, it was known that the successive loading day by day is more effective than

TABLE VI

Levels of Riboflavin in Blood after Loading

The figures are the averages of 4 cases, expressed in $\mu \mathrm{g}$. per $100 \mathrm{ml}$.

\begin{tabular}{|c|c|c|c|}
\hline $\begin{array}{l}\text { Amount of riboflavin } \\
\text { administered }\end{array}$ & $\begin{array}{l}\text { Type of } \\
\text { riboflavin }\end{array}$ & Mild & Severe \\
\hline Not loaded & $\begin{array}{l}\text { Total } \\
\text { Esterified }\end{array}$ & $\begin{array}{l}6.2 \pm 0.5 \\
4.7 \pm 1.0\end{array}$ & $\begin{array}{l}5.5 \pm 0.4 \\
3.1 \pm 0.2\end{array}$ \\
\hline $2 \mathrm{mg}$. hypodermic injection & $\begin{array}{l}\text { Total } \\
\text { Esterified }\end{array}$ & $\begin{array}{l}5.6 \pm 1.2 \\
4.8 \pm 0.9\end{array}$ & $\begin{array}{l}5.1 \pm 0.7 \\
2.6 \pm 0.4\end{array}$ \\
\hline $5 \mathrm{mg}$, hypodermic injection & $\begin{array}{l}\text { Total } \\
\text { Esterified }\end{array}$ & $\begin{array}{l}6.4 \pm 0.8 \\
3.9 \pm 0.9\end{array}$ & $\begin{array}{l}5.4 \pm 0.9 \\
3.4 \pm 0.8\end{array}$ \\
\hline
\end{tabular}


loading once from Tables $\mathrm{V}$ and VI.

\section{Amount of Riboflavin in Blood after Loading with Riboflavin}

After mild patients were loaded with $10 \mathrm{mg}$ of riboflavin, the amount of total and esterified riboflavin in the blood was measured successively. The total amount of the vitamin reached a maximum 45 minutes after loading, whereas the amount of esterified riboflavin 30 minutes (Fig. 1).

5. Loading with Each Type of Riboflavin

Five patients, both mild and severe, were each given $5 \mathrm{mg}$ of riboflavin, FMN and FAD, respectively, by hypodermic injection, and the types of the vitamin were examined. When FMN and FAD were loaded, the esterified riboflavin in the urine exhibited higher values than when riboflavin alone was loaded, and in either case, no significant difference was apparent between the mild and the severe (Table VII).

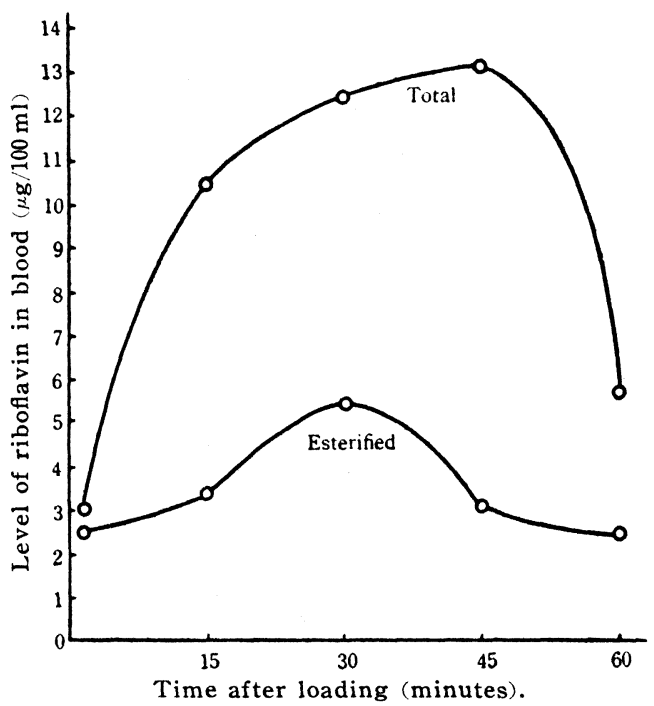

FIs. 1 Level of Riboflavin in Blood after Loading

$10 \mathrm{mg}$ of Riboflavin was Hypodermically Injected.

TABLE VII

Amounts of Riboflavin Excreted in the Urine after Loading with Various Types of Riboflavin

Figures are the averages of 5 cases, expressed in $\mu \mathrm{g}$.

\begin{tabular}{llrr}
\hline \multicolumn{1}{c}{ Amount of riboflavin } & $\begin{array}{l}\text { Type of } \\
\text { riboflavin }\end{array}$ & Mild & Severe \\
\hline $\begin{array}{l}5 \mathrm{mg} \text { Riboflavin, hypodermic } \\
\text { injection }\end{array}$ & $\begin{array}{l}\text { Total } \\
\text { Esterified }\end{array}$ & $\begin{array}{r}1397.0 \pm 95.9 \\
75.5 \pm 2.3\end{array}$ & $\begin{array}{r}1211.5 \pm 601.1 \\
110.7 \pm 45.8\end{array}$ \\
\hline $\begin{array}{l}5 \mathrm{mg} \text { FMN, hypodermic } \\
\text { injection }\end{array}$ & Total & $1975.1 \pm 385.4$ & $1954.1 \pm 457.5$ \\
& Esterified & $224.4 \pm 63.6$ & $172.8 \pm 50.3$ \\
\hline $\begin{array}{l}5 \mathrm{mg} \text { FAD, hypodermic } \\
\text { injection }\end{array}$ & Total & $1466.0 \pm 847.0$ & $1826.9 \pm 773.9$ \\
& Esterified & $159.8 \pm 88.5$ & $139.4 \pm 59.7$ \\
\hline
\end{tabular}

The urine collected after loading with riboflavin, FMN and FAD, respectively, was subjected to paper chromatography. It was found in the ultraviolet light many fluorescent spots. However, of the riboflavin derivatives, only riboflavin and FMN were detected. Thirty minutes after loading the same patients, both mild and severe, with riboflavin, the amounts of esterified riboflavin in blood was lower than after loading with FMN or FAD. Although 
there was no significant difference among the amounts of total riboflavin in blood after loading with riboflavin, FMN and FAD, respectively, it was found by this experiment that the loading with FMN or FAD is more appropriate than loading with riboflavin alone (Table VIII).

TABLE VIII

Levels of Riboflavin in Blood after Loading with Various Types of Riboflavin

Figures are the averages of 5 cases, expressed in $\mu \mathrm{g}$ per $100 \mathrm{ml}$.

\begin{tabular}{|c|c|c|c|}
\hline Amount of riboflavin & $\begin{array}{l}\text { Type of } \\
\text { riboflavin }\end{array}$ & Mild & Severe \\
\hline $\begin{array}{l}5 \mathrm{mg} \text { Riboflavin, hypodermic } \\
\text { injection }\end{array}$ & $\begin{array}{l}\text { Total } \\
\text { Esterified }\end{array}$ & $\begin{array}{l}9.1 \pm 0.9 \\
3.9 \pm 0.3\end{array}$ & $\begin{array}{l}4.3 \pm 1.5 \\
3.3 \pm 1.0\end{array}$ \\
\hline $\begin{array}{l}5 \mathrm{mg} \text { FMN, hypodermic } \\
\text { injection }\end{array}$ & $\begin{array}{l}\text { Total } \\
\text { Esterified }\end{array}$ & $\begin{aligned} & 10.5 \pm 3.3 \\
& 6.6 \pm 0.03\end{aligned}$ & $\begin{array}{l}8.5 \pm 1.5 \\
4.0 \pm 0.8\end{array}$ \\
\hline $\begin{array}{l}5 \mathrm{mg} \text { FAD, hypodermic } \\
\text { injection }\end{array}$ & $\begin{array}{l}\text { Total } \\
\text { Esterified }\end{array}$ & $\begin{array}{r}10.7 \pm 2.5 \\
7.1 \pm 3.3\end{array}$ & $\begin{array}{l}9.5 \pm 1.7 \\
5.2 \pm 1.6\end{array}$ \\
\hline
\end{tabular}

\section{Effect of Loading with ATP}

Since it was known that better result is obtainable with esterified riboflavin than with riboflavin alone, the effect of adenosine triphosphate (ATP) was examined. Determination of urinary riboflavin of four mild patients revealed that the ratio of the esterified riboflavin to the total was about 62 per cent without loading with ATP, but it rose to 90 per cent after loading with $10 \mathrm{mg}$ of ATP. Further, $10 \mathrm{mg}$ of riboflavin and $10 \mathrm{mg}$ of FMN, or 10

TABLE IX

Amounts of Riboflavin Excreted in the Urine after Loading with ATP

Figures are the averages of 4 mild cases, expressed in $\mu \mathrm{g}$.

\begin{tabular}{llc}
\hline \multicolumn{1}{c}{ Amount of riboflavin } & Type of riboflavin & Urinary excretion \\
\hline & & $m g$ \\
Normal value & Total & $64.8 \pm 21.6$ \\
& Esterified & $39.9 \pm 7.4$ \\
\hline $10 \mathrm{mg}$ ATP, hypodermic injection & Total & $66.6 \pm 16.9$ \\
\hline $10 \mathrm{mg}$ Riboflavin, hypodermic & Esterified & $60.4 \pm 4.0$ \\
\hline injection & Total & $1658.3 \pm 847.8$ \\
\hline $10 \mathrm{mg}$ riboflavin $+10 \mathrm{mg}$ ATP, & Esterified & $48.4 \pm 5.6$ \\
\hline hypodermic injection & Total & $2937.7 \pm 495.7$ \\
\hline $10 \mathrm{mg}$ FMN, hypodermic injection & Esterified & $89.6 \pm 2.1$ \\
\hline $\begin{array}{l}10 \mathrm{mg} \text { riboflavin and } 10 \mathrm{mg} \text { ATP, } \\
\text { hypodermic injections in different }\end{array}$ & Total & $1578.5 \pm 695.7$ \\
regions & Esterified & $228.1 \pm 7.4$ \\
\hline
\end{tabular}


$\mathrm{mg}$ of riboflavin and $10 \mathrm{mg}$ of ATP were loaded simultaneously or separately at different regions at the same time. Either in case of loading with riboflavin and ATP or in case of loading with FMN alone, higher values for esterified riboflavin were obtained than in case of loading with riboflavin alone (Table IX).

From this, it was assumed that the value for esterified riboflavin in urine may vary with the amounts of phosphorylating compounds, such as ATP, i.e., according to the condition of metabolism.

In the same patients, somewhat higher values in the amount of riboflavin in blood were obtained 30 minutes after loading with riboflavin and ATP and with FMN. Examining separately the plasma and erythrocyte portions, the levels of the esterified riboflavin in plasma were found to be lower after loading with both riboflavin and ATP simultaneously or with FMN, riboflavin and ATP separately than after loading with riboflavin alone.

On the contrary, the levels of esterified riboflavin in erythrocytes were higher after loading with riboflavin and ATP simultaneously or with FMN than after loading with riboflavin alone. It is suggested therefore that phosphoric acid is participated in the penetration of riboflavin into the cells (Table X).

TABLE X

Levels of Riboflavin in Blood after Loading with ATP

Figures are the averages of 4 mild cases, expressed in $\mu \mathrm{g}$ per $100 \mathrm{ml}$.

\begin{tabular}{|c|c|c|c|c|}
\hline Amount of riboflavin & $\begin{array}{l}\text { Type of } \\
\text { riboflavin }\end{array}$ & $\begin{array}{l}\text { Total } \\
\text { blood }\end{array}$ & Blood & $\begin{array}{l}\text { Erythro- } \\
\text { cytes }\end{array}$ \\
\hline Not loaded & $\begin{array}{l}\text { Total } \\
\text { Esterified }\end{array}$ & $\begin{array}{l}6.4 \pm 1.2 \\
5.0 \pm 0.8\end{array}$ & $\begin{array}{l}5.7 \pm 0.8 \\
4.4 \pm 1.0\end{array}$ & $\begin{array}{l}7.8 \pm 1.4 \\
6.0 \pm 1.2\end{array}$ \\
\hline $10 \mathrm{mg}$ ATP, hypodermic injection & $\begin{array}{l}\text { Total } \\
\text { Esterified }\end{array}$ & $\begin{array}{l}4.8 \pm 0.4 \\
2.4 \pm 0.8\end{array}$ & $\begin{array}{l}4.7 \pm 0.7 \\
1.6 \pm 1.2\end{array}$ & $\begin{array}{l}4.9 \pm 0.3 \\
2.7 \pm 1.6\end{array}$ \\
\hline $\begin{array}{l}10 \mathrm{mg} \text { riboflavin, hypodermic } \\
\text { injection }\end{array}$ & $\begin{array}{l}\text { Total } \\
\text { Esterified }\end{array}$ & $\begin{array}{r}12.4 \pm 1.6 \\
6.5 \pm 2.1\end{array}$ & $\begin{array}{r}14.4 \pm 1.5 \\
7.3 \pm 1.4\end{array}$ & $\begin{array}{l}9.6 \pm 0.9 \\
6.4 \pm 2.5\end{array}$ \\
\hline $\begin{array}{l}10 \mathrm{mg} \text { riboflavin }+10 \mathrm{mg} \text { ATP, } \\
\text { hypodermic injection }\end{array}$ & $\begin{array}{l}\text { Total } \\
\text { Esterified }\end{array}$ & $\begin{array}{r}13.7 \pm 1.9 \\
7.8 \pm 1.8\end{array}$ & $\begin{array}{r}17.7 \pm 1.9 \\
5.4 \pm 2.3\end{array}$ & $\begin{array}{l}9.3 \pm 1.0 \\
8.8 \pm 2.9\end{array}$ \\
\hline $10 \mathrm{mg}$ FMN, hypodermic injection & $\begin{array}{l}\text { Total } \\
\text { Esterified }\end{array}$ & $\begin{array}{r}15.1 \pm 2.1 \\
6.7 \pm 2.0\end{array}$ & $\begin{array}{r}13.0 \pm 1.7 \\
4.8 \pm 2.2\end{array}$ & $\begin{array}{r}17.2 \pm 1.5 \\
8.2 \pm 2.8\end{array}$ \\
\hline \multirow{2}{*}{$\begin{array}{l}10 \mathrm{mg} \text { riboflavin and } 10 \mathrm{mg} \text { ATP, } \\
\text { hypodermic injection in different } \\
\text { regions }\end{array}$} & Total & $12.0 \pm 2.3$ & $16.6 \pm 2.6$ & $6.8 \pm 0.7$ \\
\hline & Esterified & $4.6 \pm 1.1$ & $5.5 \pm 2.3$ & $3.7 \pm 1.9$ \\
\hline
\end{tabular}

\section{SUMMARY}

The amounts of total and esterified riboflavin in the total 24-hour urine and in the blood of tuberculous patients, mild, moderate and severe, were determined and there was no significant difference among the severity of the disease, no riboflavin deficiency symptoms being apparent. However, it seems 
to reveal the differences of metabolism according to the condition of illness that the levels of riboflavin, especially of esterified forms, become higher, as the symptom advances for the better.

In the loading test, more than $2 \mathrm{mg}$ of riboflavin is required for every day loading. The loading was found to be more appropriate to carry out every day with small portion than once with a large amount, since the levels of riboflavin in blood before breakfast in the morning following the loading more elevated after receiving successive injections day by day than receiving an injection of the vitamin once. In case of successive loading with $2 \mathrm{mg}$ of riboflavin every day, more amount the vitamin was excreted in the urine by the severe than the mild, whereas in case of loading with the vitamin once, the less riboflavin was excreted in the urine, the milder was the symptom. It is possibly to be considered, that the mild patients have retained more riboflavin in the bodies than the severe prior to loading in case of loading once, and that the loaded riboflavin is utilized more by the mild patients than by the severe after successive loading with $2 \mathrm{mg}$ of riboflavin. The loaded riboflavin is thought to be phosphorylated, and activated by coupling with a protein; accordingly, FMN and FAD are considered to be better suited for the loading than riboflavin. It was in fact in agreement with the results of this experiment. In the case of every day loading, the levels of the vitamin in blood are elevated, so that it may not be necessary to consider especially the time of the loading.

That more esterified riboflavin is excreted in urine after loading with the vitamin together with ATP than otherwise is thought to be due to the metabolic condition of phosphorylated compounds. After administering ATP together with riboflavin, the level of the vitamin in erythrocytes was higher than without ATP, suggesting that ATP is participated in the penetration of the vitamin in the cells.

\section{ACKNOWLEDGMENT}

The author expresses his hearty thanks to Dr. Saburo Watanabe, President of Toneyama Hospital, for his kind guidance, and to Dr. Masayasu Yamazaki, for cooperation in this research.

\section{REFERENCES}

1. Watanabe, S., J. Vitaminol. 2, 200 (1956).

2. Nakagawa, I., Vitamins 7, 699 (1954).

3. Murata, K., and Shiga, S., ibid. 4, 355 (1951).

4. Brown, W. O., Nature 169, 454 (1952).

5. Mann, G. V., J. Nutrition 47, 225 (1952).

6. Bessey, O. A., Ann. Rev. Biochem. 22, 545 (1953).

7. Horwitt, M. K., J. Nutrition 39, 357 (1949).

8. Williams, R. D. D., ibid. 27, 165 (1944).

9. Ninomiya, T., Vitamins 4, 1 (1951).

10. Abe, T., Nihon Rinsho 15, 108 (1957).

11. Yagi, K., Vitamins 7, 806 (1954).

12. Fujiwara, M., ibid. 6, 791 (1953).

13. Fujita, A., Determination of Vitamins (Jap.) p. 298, Nankodo (1955). 